\title{
CONNECTIVE TISSUE METABOLISM IN PATIENTS WITH JUVENILE IDIOPATHIC ARTHRITIS: 10-YEAR FOLLOW-UP STUDY
}

\author{
Shevchenko N.S. ${ }^{1,2}$, Panko N.O. ${ }^{1}$, Rakovska L.O. ${ }^{1}$, Holovko T.O. ${ }^{1}$ \\ ${ }^{1}$ Department of Pediatrics No. 2, V.N. Karazin Kharkiv National University, \\ ${ }^{2}$ SI "Institute of Children and Adolescences Health Care \\ of National Academy of Medical Science"
}

\begin{abstract}
Introduction. Connective tissue remodeling is essential for progressive course of juvenile idiopathic arthritis (JIA), therefore changes in glucosaminoglycans (GAGs) fractions with time in patients with JIA have been studied during 10-year follow-up. Subjects and Methods. The study involved 22 healthy children (controls) and 83 patients with JIA aged from 2 to 18 . The follow up study was yearly held for 10 years and initially included 14 patients with JIA investigated for connective tissue metabolism. Results. Proteoglycans metabolism in children with JIA is characterized by a decrease in the total GAGs, mainly by means of low levels of chondroitin-4-sulfate and highly sulphonated GAGs. This redistribution was more specific for children with prolonged disease duration (more than 5 years). Slowing of proteoglycans metabolism in reducing the excretion of uronic acids was the most common for up to 2 years of disease duration as compared to later stages. Conclusions. The severity of metabolic imbalance of proteoglycans depends on the duration of JIA and has the most unfavorable period of 5 years and later after the onset of the disease.
\end{abstract}

Keywords: juvenile idiopathic arthritis, connective tissue metabolism.

\section{Introduction.}

The major clinical presentation of juvenile idiopathic arthritis (JIA) is known to be the persistent synovial inflammation that can lead to irreversible joint destruction and permanent disability in childhood. The complex pathogenesis of JIA has been studied in sufficient detail, but it has not been fully explained yet. Despite significant progress in the treatment of JIA, the risk of disease progression remains high. The findings of the recent investigation have revealed microstructural changes indicative of cartilage damage in JIA patients by new imaging methods, in spite of clinical improvement and before changes in cartilage morphology which can be detected with conventional magnetic resonance imaging [6]. The impact of various mechanisms on the development of cartilage erosion in JIA continues to be the subject of scientific research.

Corresponding Author:

Nataliya Panko, MD, PhD, Associate Professor of Department of Pediatrics No. 2 of V.N. Karazin Kharkiv National University, Ukraine.

E-mail:panko@karazin.ua
Metabolic alterations of extracellular matrix (ECM) components have been shown to play a considerable role in pathological changes in the course of JIA $[4,13,15,16]$.

ECM is a complex and dynamic structure, composed of two main classes of macromolecules: proteoglycans (PGs) and fibrous-forming proteins, such as collagen, elastin, fibronectin, and laminin [2]. PGs consist of a core protein with covalently attached one or more glucosaminoglycans (GAGs) chains of the same or different type [2, 12]. PGs form a hydrated gel that fills the majority of extracellular interstitial space [2]. PGs have been classified according to their core proteins, localization and GAGs composition. The GAGs chains on the protein core are unbranched polysaccharide chains composed of repeating disaccharide units that can be further divided into sulfated and non-sulfated GAGs [2, 16]. Sulfated GAGs include chondroitin sulfate A (or chondroitin-4-sulfate), chondroitin sulfate $\mathrm{C}$ (or chondroitin-6-sulfate) and highly sulphonated GAGs (or heparan sulfate and keratan sulfate $(\mathrm{KS})$ ). 
Hyaluronic acid, chondroitin sulfate (CS) and highly sulphanated GAGs are considered to be the main components of GAGs in humans.

The major PG in cartilage is aggrecan, which is a large proteoglycan bearing numerous $\mathrm{CS}$ and KS chains expressed by chondrocytes. A typical aggrecan molecule may contain up to $100 \mathrm{CS}$ chains and a lower number of KS chains. Aggrecan endows articular cartilage with the ability to withstand compressive loads [1,2]. CS is considered to be an early marker of aggrecan degradation [14].

The disorganization of ECM components' metabolism and structural changes of PGs and collagen is believed to occur in early stages of JIA, and, furthermore, degradation elements of ECM structures have antigenic properties which may maintain progress of immune inflammation and extend the destructive process into deeper structures of the joint [8, 13-16]. Aggrecan degradation products occur in blood, and they are free CS chains or the chains of GAGs bound to core protein fragments [14].

The studies to determine sulphated GAGs in JIA synovial fluids have demonstrated a significantly lower concentration as compared to the levels of fluids in osteoarthritis, juvenile knee injury and kneehealthy reference groups. The authors suggest that unlike other arthritides, aggrecanase cleavage in the aggrecaninterglobular domain might not be a major pathogenic event in JIA [11].

A decreased serum concentration of GAGs resulting from the substantial reduction of sulfated glycans, particularly CS was detected in untreated children with newly diagnosed JIA $[13,14,17]$. The increased levels of dermatan sulfate and hyaluronic acid were also observed in untreated JIA patients [17]. The researchers consider that at the moment of clinical symptoms appearance the total pool of GAGs is significantly reduced, while the processes of ECM components' synthesis do not compensate the degradation of these compounds. In addition, the total amount of GAGs was significantly lower than in healthy children [13]. The low levels of GAGs in blood were accompanied with their decreased urinary excretion [17].

The low concentration of CS recorded in serum of JIA patients with untreated arthroplasty was found to have a negative statistically significant correlation with concentrations of laboratory inflammatory markers, such as Creactive protein and ESR. Therefore, the researchers have concluded that the concentration of CS in blood of children with arthropathy is directly related to the activity of both inflammatory processes and proteolytic degradation of ECM components [14]. At the same time, the serum level of chondroitin sulfate 846 epitope (CS846) as a biomarker of CS synthesis was increased significantly.

According to the above-mentioned studies the anti-inflammatory treatment of children with JIA leads to clinical improvement, but does not normalize blood GAG concentrations [14, 15]. Despite the increased content of these compounds in treated patients, their level is still significantly lower than in healthy children. The authors believe that increased concentration of GAGs observed during treatment may indicate an ongoing regenerating processes in connective tissue. The observed changes of $\mathrm{PG} / \mathrm{GAG}$ metabolism in children with JIA are also suggested to be related to the auto-immune mechanisms of the disease, such as presence of GAG-specific antibodies in the systemic circulation and in the synovial fluid of rheumatoid arthritis patients. They come to the conclusion that at the active phase of the disease the levels of anti-GAG antibodies have reduced due to their binding to GAGs, released from the degrading cartilage, resulting in diminishing the general amount of GAGs in plasma [16].

Nevertheless, the qualitative and quantitative evaluation of plasma GAGs of rheumatoid arthritis adult patients in relation to the disease activity has revealed higher levels of total GAGs, CS, heparan sulfate/heparin and hyaluronic acid in patients with high and moderate disease activity than in controls. Total GAGs and CS levels in patients with high disease activity have been elevated in comparison to patients with low disease activity [5]. Thus, plasma concentration of various GAGs types, which reflects tissue alterations of ECM, is suggested to be dependent on the age [14].

It has also been shown that an essential feature of the connective tissue state in children and adolescents with rheumatoid and reactive arthritis is metabolic changes of its structures, accompanied with a progressive loss of basic functionally important components of the extracellular matrix, but with a more pronounced pathological component for juvenile rheumatoid arthritis. The basic reflection of the development of dystrophic changes is the deficiency state of GAGs, mainly due to chondroitin-4-sulfates and highly sulphonated GAGs [9].

Taking into account the essential importance of metabolic alteration of ECM as well as 
systemic changes in connective tissue remodeling for progressive course of JIA, changes in GAGs fractions with time in patients with JIA have been studied during 10-year follow-up.

2 Purposes, subjects and methods:

2.1 Purpose - to improve medical care for patients with the progressive course of JIA by 10-year follow-up analysis of changes in GAGs fractions with time.

\subsection{Subjects \& Methods}

The study involved 22 healthy children for the control group and 83 patients with JIA aged from 2 to 18 including $39.60 \%$ cases of oligoarthritis, $37.70 \%$ off polyarticular form, $20.8 \%$ of systemic form, $1.90 \%$ of enthesitisrelated arthritis. And $61.45 \%$ of them were females, $38.55 \%$ were males. The follow up study was held for 10 years and initially included 14 patients with JIA investigated for connective tissue metabolism. Their examination was repeated yearly. All patients received basic therapy with methotrexate.

Connective tissue metabolism parameters were assessed depending on the disease duration: up to 1 year (14 patients), 1-2 years (11 patients), 2-3 years (11 patients), 3-5 years (13 patients) and 5-10 years (34 patients).

The investigation of connective tissue metabolism implied measurement of the total glucosaminoglycans (GAGs) level, the total chondroitin sulfate level [3, 7], containing chondroitin-6-sulfate and chondroitin-4-sulfate, the level of highly sulphonated GAGs (keratan and dermatan sulfate) in blood [10]; and excretion rate of uronic acid [3, 7]. Clinical and immunological parameters, such as the level of general T-lymphocytes, T-helpers and T-suppressors, the level of circulated immune complexes, spontaneous and induced Nitro Blue Tetrazolium Reduction tests, neutrophil phagocytic activity, the level of interleukin $1 \beta$ (IL-1 $\beta$ ), interleukin 6 (IL-6) and tumor necrotic factor (TNF-a) were assessed.

Statistical analysis was performed using Statistica+ software for Windows. The differences between the study groups were assessed by Student's t-test $(\mathrm{t})$. A $p$-value of $<0.05$ was considered statistically significant.

\section{Availability of data and materials}

The datasets generated and/or analyzed during the current study are not publicly available for ethical reasons, as well as privacy reasons, but are available from the authors on reasonable request.

Ethics approval and consent to participate

Approval from medical research ethical committees and data protection authorities was granted according to the regulations of Ukraine. Oral informed assent was obtained from all children. Written informed consent was obtained from parents of children aged $<18$ years and from the children if aged $\geq 14$ years of age.

\section{Results and discussion}

The study of connective tissue components has shown that the children and adolescents with JIA had misbalance of PGs structures. The average total GAGs content, the level of serum chondroitin-6-sulfate and the concentration of uronic acid in daily urine in the investigated patients with JIA were probably no different from those in the similar aged healthy children. The study showed increased content of chondroitin4-sulphate $((2.76 \pm 0.53)$ units, $\mathrm{p}<0.05)$ and highly sulphanated GAGs $((1.32 \pm 0.15)$ units, $\mathrm{p}<0.05)$ in patients with JIA in comparison with the control group. That fact indicates the development of dystrophic process and corresponds to destructive changes in connective tissue.

Depending on the gender of children with JIA the following features were established to be more specific for female patients, represented with changes of all types of proteoglycans, except chondroitin-6-sulfate (table 1).

Table 1

Connective tissue metabolism parameters in patients with JIA corresponding to gender

\begin{tabular}{|c|c|c|c|c|c|c|}
\hline \multirow{3}{*}{$\begin{array}{c}\text { Parameters } \\
1\end{array}$} & \multicolumn{2}{|c|}{$\begin{array}{c}\text { Patients with JIA } \\
n=58\end{array}$} & \multirow{3}{*}{$\begin{array}{l}\text { Control group } \\
\qquad \begin{array}{c}n=22 \\
4 \\
M \pm m\end{array}\end{array}$} & \multirow{2}{*}{\multicolumn{3}{|c|}{$\begin{array}{l}\text { statistically significant } \\
\text { difference } \\
\left(\mathrm{p}_{\mathrm{t}}\right)\end{array}$}} \\
\hline & \multirow{2}{*}{$\begin{array}{c}\text { male } \\
\mathrm{n}=30 \\
2 \\
\mathrm{M} \pm \mathrm{m}\end{array}$} & \multirow{2}{*}{$\begin{array}{c}\text { female } \\
n=28 \\
3 \\
M \pm m\end{array}$} & & & & \\
\hline & & & & $2-3$ & $2-4$ & $3-4$ \\
\hline Total GAGs, U & $10.46 \pm 0.63$ & $9.14 \pm 2.51$ & $10.01 \pm 0.38$ & $<0.01$ & $>0.05$ & $>0.05$ \\
\hline Chondroitin-6-sulphate, U & $7.16 \pm 0.39$ & $8.12 \pm 0.95$ & $6.83 \pm 0.27$ & $>0.05$ & $>0.05$ & $<0.05$ \\
\hline Chondroitin-4-sulphate, U & $2.21 \pm 0.37$ & $3.64 \pm 1.23$ & $2.01 \pm 0.14$ & $<0.05$ & $>0.05$ & $<0.05$ \\
\hline Highly sulphonated GAGs, U & $1.14 \pm 0.07$ & $1.62 \pm 0.37$ & $1.21 \pm 0.09$ & $<0,01$ & $>0.05$ & $<0.05$ \\
\hline Total CS, g/l & $0.13 \pm 0.01$ & $0.67 \pm 0.98$ & $0.12 \pm 0.01$ & $<0.01$ & $>0.05$ & $<0.01$ \\
\hline Uronic acid, mg/d & $5.08 \pm 0.87$ & $9.02 \pm 2.56$ & $7.46 \pm 2.14$ & $<0.01$ & $<0.05$ & $>0.05$ \\
\hline
\end{tabular}


The total level of GAGs was lower ((9.14 \pm $2.51)$ units vs $(10.46 \pm 0.63)$ units, $p<0.01)$ in females as compared to males. Thus, there was significantly higher chondroitin-4-sulfate content, $((3.64 \pm 1.23)$ units and $(2.21 \pm 0.37)$ units respectively, $\mathrm{p}<0.05)$ and the level of highly sulphanated GAGs $((1.62 \pm 0.37)$ units and $(1.14 \pm$ $0.07)$ units respectively, $p<0.01)$. These changes in proteoglycans content in blood were accompanied by higher level of uronic acid excretion in females compared to male patients $((9.02 \pm 2.56) \mathrm{mg} / \mathrm{d}$ and $(5.08 \pm 0.87) \mathrm{mg} / \mathrm{d}, \mathrm{p}<0.01$ respectively). This redistribution of proteoglycans content is more common for degenerative processes, such as an initiation of osteoarthritis; it gives a reason to believe female sex is one of the risk factors for early formation of osteoarthritis secondary to JIA. That fact is proved by the correlation of the female sex with chondroitin sulfate content $(\mathrm{r}=$ $0.57 ; \mathrm{p}<0.05)$, the total level of GAGs $(\mathrm{r}=-0.56$; $\mathrm{p}<0.05)$, chondroitin-6-sulfate $(\mathrm{r}=0.55 ; \mathrm{p}<0.05)$, chondroitin-4-sulphate $(\mathrm{r}=0.72 ; \mathrm{p}<0.01)$ and highly sulphanated GAGs $(\mathrm{r}=0.58 ; \mathrm{p}<0.05)$, the level of excretion of uronic acids $(r=0.62$; $\mathrm{p}<0.05$ ).

The elevation of levels of general activity of the pathological process is characterized by progressive decreasing of chondroitin-4-sulfate and highly sulphanated GAGs contents with simultaneous increase in uronic acids excretion. This redistribution of proteoglycans components is one of more evidence of the impact of inflammation on the intensity of proteoglycans metabolism and it is different from dystrophic changes.

The radiological progression was established to be accompanied by a redistribution of proteoglycans too. More severe changes in the metabolism of proteoglycans occur in children with JIA, who had radiological stage II, than in patients with radiographic stage I. They were as follows: the reduction of total GAGs $((9.25 \pm 0.77)$ units compared with $(13.05 \pm 0.07)$ units, $\mathrm{p}<0.001)$ ) and the content of chondroitin-4sulphate $((1.80 \pm 0.42)$ units compared with $(2.75$ $\pm 0.06)$ units, $\mathrm{p}<0.001)$ ) while growing content of highly sulphanated GAGs $((2.65 \pm 0.05)$ units compared with $(1.10 \pm 0.56)$ units, $\mathrm{p}<0.01)$.

The significant differences were not determined by the analysis of proteoglycans metabolism according to the disease duration; all values were equivalent (table 2). At the same time, due to the comparison with the same parameters of the control group the largest deviations were recorded on the early stages of the disease development, which was associated with the activity of pathological process before or at the beginning of anti-inflammatory treatment.

The content of chondroitin-4-sulfate decreased as the result of increasing disease duration. The patients with disease history exceeding 5 years were found to have the most significant difference as compared to previous years $((1.37 \pm 0.12)$ units and $(2.05 \pm 0.55)$ units respectively, $\mathrm{p}<0.05))$. It might have accompanied the dystrophic processes in the connective tissue.

Table 2

Parameters of connective tissue metabolism corresponding to duration of JIA

\begin{tabular}{|c|c|c|c|c|c|c|c|}
\hline \multirow[b]{2}{*}{ Parameters } & \multicolumn{6}{|c|}{ Duration of $\mathrm{JIA}(\mathrm{M} \pm \mathrm{m})$} & \multirow[b]{2}{*}{$\begin{array}{l}\text { Control } \\
\text { group }\end{array}$} \\
\hline & $\begin{array}{l}\text { Up to } 12 \\
\text { months } \\
(n=14)\end{array}$ & $\begin{array}{c}\text { From } 13 \text { to } 24 \\
\text { months } \\
(n=11)\end{array}$ & $\begin{array}{c}\text { From } 25 \text { to } 36 \\
\text { months } \\
(n=11)\end{array}$ & $\begin{array}{l}\text { From } 37 \text { to } \\
60 \text { months } \\
(n=13)\end{array}$ & $\begin{array}{l}\text { From } 61 \text { to } \\
120 \text { months } \\
(n=34)\end{array}$ & $\begin{array}{c}\text { Total } \\
\text { number of } \\
\text { cases } \\
(\mathrm{n}=83)\end{array}$ & \\
\hline Total GAGs, U & $10.53 \pm$ & & & $0.53 \pm 2.28$ & $8.67 \pm$ & $10.24 \pm 0.47$ & 10.01 \\
\hline $\begin{array}{l}\text { Chondroitin-6- } \\
\text { sulphate, U }\end{array}$ & $6.76 \pm 0.97$ & $6.63 \pm 0.52$ & $6.20 \pm 0.50$ & $6.76 \pm 0.97$ & $5.93 \pm 0.75^{4)}$ & $6.21 \pm 0.16$ & $6.83 \pm 0.27$ \\
\hline $\begin{array}{l}\text { Chondroitin-4- } \\
\text { sulphate, U }\end{array}$ & $2.13 \pm 0.65$ & $2.00 \pm 0.21$ & $2.75 \pm 1.25$ & $2.05 \pm 0.55$ & $1.37 \pm 0.12^{3 / 4)}$ & $2.12 \pm 0.17$ & $2.01 \pm 0.14$ \\
\hline $\begin{array}{l}\text { Highly } \\
\text { sulphonated } \\
\text { GAGs, U }\end{array}$ & $1.63 \pm 0.23$ & $1.50 \pm 0.21^{1)}$ & $2.05 \pm 0.55$ & $1.63 \pm 0.23$ & $1.47 \pm 0.19^{2)}$ & $1.91 \pm 0.31^{4)}$ & $1.21 \pm 0.09$ \\
\hline Total CS, g/l & $0.12 \pm 0.06$ & $0.07 \pm 0.00$ & $0.07 \pm 0.02$ & $0.07 \pm 0.00$ & $0.10 \pm 0.04$ & $0.11 \pm 0.01$ & $0.12 \pm 0.01$ \\
\hline $\begin{array}{l}\text { Uronic acid, } \\
\mathrm{mg} / \mathrm{d}\end{array}$ & $3.65 \pm 0.91$ & $2.53 \pm 0.84^{1)}$ & $3.35 \pm 1.05$ & $2.40 \pm 0.60$ & $4.20 \pm 0.72$ & $3.59 \pm 0.34$ & $7.46 \pm 2.14$ \\
\hline \multicolumn{8}{|c|}{$\begin{array}{l}\text { 1) } p_{\mathrm{t}}<0.05 \text { - the difference between parameters in patients with disease duration from } 13 \text { to } 24 \text { months and from } 25 \\
\text { to } 36 \text { months; } \\
\text { 2) } p_{\mathrm{t}}<0.05 \text { - the difference between parameters in patients with disease duration from } 13 \text { to } 24 \text { months and from } 61 \\
\text { to } 120 \text { months; } \\
\text { 3) } p_{\mathrm{t}}<0.05 \text { - the difference between parameters in patients with disease duration from } 37 \text { to } 60 \text { months and from } 61 \\
\text { to } 120 \text { months; } \\
\text { 4) } p_{\mathrm{t}}<0.05 \text { - the difference between parameters in patients with JIA and healthy children from control group. }\end{array}$} \\
\hline
\end{tabular}


Proteoglycans metabolism in children with JIA is characterized by a decrease in total GAGs, mainly by means of low levels of chondroitin-4sulfate and highly sulphonated GAGs. This redistribution was more specific for children with prolonged disease duration (more than 5 years). It can be assessed as a precondition for the development of osteoarthritis of affected joints.

Slowing of proteoglycans metabolism in reducing the excretion of uronic acids was the most common for up to 2 years of disease duration as compared to later stages $((2.53 \pm 0.84) \mathrm{mg} / \mathrm{d}$ and $(3.35 \pm 1.05) \mathrm{mg} / \mathrm{d}$ respectively, $\mathrm{p}<0.05)$. It was associated with period of more active treatment and the most satisfactory clinical benefits. Along with this, a high content of GAGs as a reflection of inflammatory activity of the disease was detected, reflecting an abnormal inflammatory process.

The duration and activity of the disease have an effect on connective tissue metabolism, that was approved by correlating the duration of JIA with content of chondroitin-4-sulfate $(r=-0.37$; $\mathrm{p}<0.05$ ); the number of active joints with the level of chondroitin-6-sulfate $(r=-0.39 ; p<0.05)$ and the level of total chondroitin sulfate $(\mathrm{r}=0.37$; $\mathrm{p}<0.05$ ).

The significance of changes in biochemical homeostasis in patients with JIA is proved by versatility of correlation between indices of immune system and parameters of connective tissue metabolism. The correlations were established between the following parameters of blood: serum calcium correlated with the level of general T-lymphocytes $(\mathrm{r}=0.61 ; \mathrm{p}<0.01)$, induced Nitro Blue Tetrazolium Reduction test $(\mathrm{r}=0.58 ; \mathrm{p}<0.02)$ and the level of TNF- $\alpha(\mathrm{r}=$ $0.94 ; \mathrm{p}<0.001$ ); magnesium in blood correlated with blood level of circulating immune complexes $(\mathrm{r}=0.54 ; \mathrm{p}<0.03)$; phosphorus blood correlated with T-helpers level $(\mathrm{r}=0.42 ; \mathrm{p}<0.05)$, T-suppressors rate $(r=0.43 ; p<0.05)$; chondroitin sulfates of blood correlated with phagocytes number $(\mathrm{r}=0.65 ; \mathrm{p}<0.001)$, T-suppressors rate $(\mathrm{r}=-0.84 ; \mathrm{p}<0.001)$, the complement content $(\mathrm{r}=0.62 ; \mathrm{p}<0.01)$, the level of $\operatorname{IgG}(\mathrm{r}=0.50$; $\mathrm{p}<0.05)$ and the content of IL- $6(\mathrm{r}=0.44 ; \mathrm{p}<0.05)$; the oxyproline excretion correlated with neutrophil phagocytic activity $(\mathrm{r}=0.45 ; \mathrm{p}<0.05)$, spontaneous Nitro Blue Tetrazolium Reduction test $(\mathrm{r}=-0.60$; $\mathrm{p}<0.02$ ). and induced Nitro Blue Tetrazolium Reduction test $(r=-0.56 ; p<0.01)$; the total GAGs level correlated with the level of circulating immune complexes $(\mathrm{r}=0.57 ; \mathrm{p}<0.02)$, T-suppressors rate $(\mathrm{r}=0.69 ; \mathrm{p}<0.01), \operatorname{IgM}(\mathrm{r}=0.47$; $\mathrm{p}<0.05)$; the content of highly sulphanated GAGs correlated with $\mathrm{T}$-suppressors rate $(\mathrm{r}=0.49$; $\mathrm{p}<0.05$ ), the level of circulating immune complexes $(r=0.91 ; p<0.001)$.

Due to the analysis of correlations almost all studied parameters were involved in correlation the most actively in the period of disease duration from three to five years, confirming polycomponent pathological process. At this stage of the disease cornerstone parameters was the concentration of calcium, phosphorus and to a lesser extent the parameters of collagen metabolism. The isolated correlations were formed involving cholesterol, total GAGs and serum magnesium. It might be a background for the development of osteopenic syndrome and degenerative processes in the connective tissue.

At the time of disease duration over five years among the biochemical indices in creating ties components dominated and were characterized by the structural composition of proteoglycans and magnesium content of blood. It indicates the importance of their deviations in further progression of structural changes in the joints.

Among immunological parameters the most prominent correlation with biochemical parameters was in cell immunity link, T-suppressors were responsible for biochemicallyimmunological integration during the disease development.

On the other hand, a large number of multiple correlation dependencies at more distant stages of disease duration testify the instability of body systems secondary to the disease development, which leads to insufficient compensation in the event of changes in different parameters of metabolism. It may be a prerequisite for further progression of dystrophic changes in the connective tissue.

\section{Discussion}

Information about changes of connective tissue metabolism in patients with JIA was widely published. Plenty of studies showed disorganization of ECM component metabolism and structural changes of PGs and collagen, maintaining progress of immune inflammation and extending the destructive process into deeper structures of the joints [4, 13-17]. As a result of our study, the features of connective tissue metabolism were established to be more specific for female patients, represented with changes of all types of proteoglycans, except, chondroitin-6sulfate. That fact was proved by the correlation of the female sex of JIA patients with the CS content, the total level of GAGs, the amounts of 
chondroitin-6-sulfate, chondroitin-4-sulphate, highly sulphanated GAGs and the level of excretion of uronic acids. The similar results we reported earlier [9]. The decreased serum concentration of GAGs resulting from the substantial reduction of sulfated proteoglycans, particularly CS in untreated children with newly diagnosed JIA $[9,13,14,17]$, the increased levels of dermatan sulfate and hyaluronic acid in untreated JIA patients $[9,17]$ were recorded before. Cohort of the patients in our research included children with JIA, who were treated with methotrexate initially. In our opinion, it was one of the reasons of difference absence in the average total GAGs content, the level of serum chondroitin-6-sulfate and the concentration of uronic acid in daily urine in the patients with JIA under study generally in comparison with those in the similar aged healthy children. Corresponding to the results of our follow-up study the total amount of GAGs, chondroitin-6-sulfate and chondroitin-4-sulphate in spite of treatment was significantly lower than in healthy children only in patients with disease duration more then 5 years, which corresponded with the reports of our Polish colleagues [13, 17]. On the one hand, the similarity with other researches was recorded regarding the increased levels of highly sulphanated GAGs in JIA patients in comparison with healthy children [17]. On the other hand, our results showed that the level of highly sulphanated GAGs depended on JIA duration, because its content in the group of patients with disease history exceeding 5 years was lower then on previous stages. The significance of changes in biochemical homeostasis in patients with JIA is proved by versatility of correlation between immune system indices and connective tissue metabolism parameters. Serum content of chondroitin sulfates correlated with phagocytes number, T-suppressors rate, the complement content, the level of IgG and the content of IL-6; the content of highly sulphanated GAGs correlated with T-suppressors rate and the level of circulating immune complexes. Corresponding to our research and literature data the anti-inflammatory treatment of children with JIA leads to clinical improvement, but does not normalize connective tissue metabolism $[14,15]$.

\section{Conclusions}

The research has identified a significant imbalance of the structural components of proteoglycans matrix of the connective tissue in children with JIA. These changes are reflective of the presence of the metabolic activity due to the inflammatory process.

The accumulation of dermatan- and keratancontaining fractions of GAGs indicates the disintegration of proteoglycans chains with the possible development of dystrophic changes as early as in childhood secondary to JIA.

Females with JIA are at risk for the possible development of secondary osteoarthritis.

High disease activity is a major predictor of the development of degenerative changes in joints that is proved by the multiple correlation relationships between the indices of proteoglycans metabolism, the inorganic elements and the parameters of immunological homeostasis of the blood.

The severity of metabolic imbalance of proteoglycans depends on the duration of JIA.

The revealed changes can be the basis for pharmacological correction of biochemical composition of connective tissue structures in order to prevent the development of secondary dystrophic changes in the affected joints in children with JIA, and reflect the insufficient effectiveness of the treatment and persistence of subclinical activity of inflammation.

\section{Declarations:}

\section{Acknowledgements}

First, we thank the children and parents participating in the study. We also thank the scientists and clinicians of hospital of SI "Institute of children and adolescences health care of National Academy of Medical Science".

\section{Funding}

This work was supported by administration of SI "Institute of children and adolescences health care of National Academy of Medical Science".

\section{Conflict of interests}

There is no conflict of interests.

\section{References}

1. Aspberg, A. (2012). The different roles of aggrecan interaction domains. Journal of Histochemistry \& Cytochemistry, 60(12), 987-996. doi:10.1369/0022155412464376

2. Frantz, C., Stewart, K. M., Weaver, V. M. (2010). The extracellular matrix at a glance. Journal of Cell Science, 123, 4195-4200. doi:10.1242/jcs.023820. 
3. Горячковский, А. М. (2005) Клиническая биохимия в лабораторной диагностике. Одесса: Экология. [Goryachkovskiy А. М. (2005) Klinicheskaya biokhimiya v laboratornoy diagnostike. Odessa: Ekologiya].

4. Hanyecz, A., Olasz, K., Tarjanyi, O., Nemeth, P., Mikecz, K., Glant, T. T., Boldizsar, F. (29 January 2014). Proteoglycan aggrecan conducting T cell activation and apoptosis in a murine model of rheumatoid arthritis. Biomed Research International, Volume 2014, Article ID 942148, 13 pages. http://dx.doi.org/10.1155/2014/942148

5. Jura-P??torak, A., Komosinska-Vassev, K., Kotulska, A., Kucharz, E. J., Klimek, K., KopecMedrek, M., Olczyk, K. (10 June 2014) Alterations of plasma glycosaminoglycan profile in patients with rheumatoid arthritis in relation to disease activity. Clinica chimica acta, Volume 433, 20-27. doi:10.1016/j.cca.2014.02.027.

6. Kim, H. K., Laor, T., Graham, T. B., Anton, C. G., Salisbury, S. R., Racadio, J. M., Dardzinski, B. J. (2010). T2 relaxation time changes in distal femoral articular cartilage in children with juvenile idiopathic arthritis: a 3-year longitudinal study. American Journal of Roentgenology, 195(4), 10211025. doi:10.2214/AJR.09.4019.

7. Roughley, P. J., Mort, J. M. (2014). The role of aggrecan in normal and osteoarthritic cartilage. Journal of Experimental Orthopaedics, 1(8). doi:10.1186/s40634-014-0008-7.

8. Shevchenko, N. S., Lebec, I. S., Kashkalda, D. A. (2016) Changes of connective tissue biochemical indexes in children and adolescents with inflammatory diseases of joints. The Journal of V.N. Karazin Kharkiv National University, Series: biology, Issue 26, 11-15.

9. Штерн, М. Р., Тимошенко, О. П., Леонтьева, Ф. С., Клюева, Г. Ф. Способ определения глюкозаминогликанов в сыворотке крови. Патент A.s. 960626 SSSR, M. K1 3.G 0,1 № 33148. SSSR. - №2998857128 - 13, Бюллетень № 35, 2 с. [Shtern M.P., Timoshenko O.P., Leontyeva F.S., Klyueva G.F. Sposob opredeleniya glikozaminoglikanov v syvorotke krovi. A.s. 960626 SSSR, M. K1 3.G 0,1 № 33148. SSSR. - №2998857128 - 13; Zayavl. 23.10.80. Opubl. 23.09.82. Byul. №35. 2s.]

10. Struglics, A., Lohmander, L. S., Last, K., Akikusa, J., Allen, R., Fosang, A. J. (08 August 2012). Aggrecanase cleavage in juvenile idiopathic arthritis patients is minimally detected in the aggrecaninterglobular domain but robust at the aggrecan C-terminus. Arthritis \& Rheumatism, Volume 64, Issue 12, 4151-4161. https://doi.org/10.1002/art.34665.

11. Theocharis, A. D., Skandalis, S. S., Gialeli, C., Karamanos, N. K. (1 February 2016). Extracellular matrix structure. Advanced Drug Delivery Reviews, Volume 97, 4-27. http://dx.doi.org/10.1016/ j.addr.2015.11.001.

12. Winsz-Szczotka, K., Komosicska-Vassev, K., Kuznik-Trocha, K., Gruenpeter, A., LachyrMotyka, I., Olczyk, K. (June 2014) Influence of proteolytic-antiproteolytic enzymes and prooxidativeantioxidative factors on proteoglycan alterations in children with juvenile idiopathic arthritis. Clinical Biochemistry, Volume 47, Issue 9, 829-834. https://doi.org/10.1016/j.clinbiochem.2014.01.027.

13. Winsz-Szczotka, K., Komosicska-Vassev, K., Kuznik-Trocha, K., Jura-PyBtorak, A. (January 2016). Laboratory Indicators of Aggrecan Turnover in Juvenile Idiopathic Arthritis. Disease Markers, Volume 2016, Article ID 7157169, 7 pages. https://www.hindawi.com/journals/dm/2016/7157169/.

14. Winsz-Szczotka, K., Komosicska-Vassev, K., Kuznik-Trocha, K., Siwiec, A., Эeglec, B., Olczyk, K. (2015). Circulating keratan sulfate as a marker of metabolic changes of cartilage proteoglycan in juvenile idiopathic arthritis; influence of growth factors as well as proteolytic and prooxidative agents on aggrecan alterations. Clinical Chemistry and Laboratory Medicine, 53(2): 291-297. doi:10.1515/ cclm-2014-0441.

15. Winsz-Szczotka, K., Mencner1, L., Olczyk, K. (2016). Metabolism of glycosaminoglycans in the course of juvenile idiopathic arthritis. Advances in Hygiene and Experimental Medicine, 70, 135 142. doi:10.5604/17322693.1196355.

16. Winsz-Szczotka, K., Kuznik-Trocha, K., Komosicska-Vassev, K., Wisowski, G., Gruenpeter, A., Lachyr-Motyka, I., Эeglec, B., Lemski, W., Olczyk, K. (2015). Plasma and urinary glycosaminoglycans in the course of juvenile idiopathic arthritis. Biochemical and Biophysical Research Communications, 458(3), 639-643. doi:10.1016/j.bbrc.2015.02.018.

Received: 20-Dec-2018

Accepted: 11-Mar-2019 